\title{
A RETROSPECTIVE STUDY SHOWING THE SAFETY OF MINIMALLY INVASIVE SURGERY OF CERVICAL CANCER
}

$\underline{\text { A. Ditto }}^{1}$, U. Leone Roberti Maggiore ${ }^{1}$, F. Martinelli ${ }^{1}$, G. Bogani ${ }^{1}$, M.T. Evangelista ${ }^{1}$, V. Chiappa ${ }^{1}$, V. Liberale $^{1}$, F. Murgia ${ }^{1}$, C. Sonetto ${ }^{1}$, G. Maltese ${ }^{1}$, F. Zanaboni ${ }^{1}$, F. Raspagliesi ${ }^{1}$.

${ }^{1}$ IRCCS Foundation National Cancer Institute, Gynecologic Oncology, Milan, Italy.

\section{OBJECTIVES}

Cervical cancer (CC) is the fourth most common malignancy in women worldwide. Surgical treatment, including radical hysterectomy and pelvic +/- paraaortic lymphadenectomy, is the gold standard for women with early stage CC. Recently, the LACC trial demonstrated that minimally invasive surgery was associated with lower rates of disease-free survival (DFS) and overall survival (OS) than open surgery among women with early-stage CC.

The aim of the current study was to present our experience with laparoscopic treatment of patients with CC in terms of OS and DFS as well as the type and site of recurrence.

\section{METHODS}

This was a retrospective analysis of a prospectively collected database of patients with CC who underwent laparoscopic surgery. The primary outcome of this study was to evaluate the 5-year OS and DFS. Secondary outcome was to compare the rate and the type of recurrences rate.

\section{RESULTS}

Ninety-one patients were included in this study (Table 1). All patients underwent laparoscopic radical treatment; no conversion was required. DFS was $33.7 \pm 27.2$ months. A total of 10 patients $(11.0 \%)$ had recurrence diagnosed during follow-up. Site of recurrence were: pelvis in 6 cases $(6.0 \%)$, lymph node in one case $(1.0 \%)$, lung in two cases $(2.0 \%)$ and both pleural and pelvis in 1 case (1.0\%). Time to recurrence among patient who had recurrence was $14.4 \pm 10.8$ months. OS was $32.5 \pm 27.1$ months.

\begin{tabular}{|c|c|}
\hline Age (years) & $46.3 \pm 9.9$ \\
\hline $\mathrm{BMI}\left(\mathrm{kg} / \mathrm{m}^{2}\right)$ & $24.2 \pm 4.7$ \\
\hline Histology & \\
\hline Squamous cell & $64(64.0)$ \\
\hline Adenocarcinoma & $29(29.0)$ \\
\hline Other type & $7(7.0)$ \\
\hline Grade & \\
\hline 1 & $14(14.0)$ \\
\hline 2 & $30(30.0)$ \\
\hline 3 & $48(48.0)$ \\
\hline Missing data & $8(8.0)$ \\
\hline Figo stage & \\
\hline IA1 & $9(9.0)$ \\
\hline IA2 & $8(8.0)$ \\
\hline IB1 & $47(47.0)$ \\
\hline IB2 & $13(13.0)$ \\
\hline IIA & $2(2.0)$ \\
\hline IIB & $21(21.0)$ \\
\hline LVSI & \\
\hline No & $48(48.0)$ \\
\hline Yes & $43(43.0)$ \\
\hline Missing data & $9(9.0)$ \\
\hline Lymph node & \\
\hline Negative & $257(79.1)$ \\
\hline Positive & $68(20.9)$ \\
\hline Pelvic lymphadenectomy & \\
\hline Performed & $324(99.7)$ \\
\hline Sampling & $1(0.3)$ \\
\hline Not performed & $0(0)$ \\
\hline Para-aortic lymphadenectomy & \\
\hline Performed & $31(9.6)$ \\
\hline Sampling & $17(5.2)$ \\
\hline Not performed & $277(85.2)$ \\
\hline NACT & \\
\hline No & $65(65.0)$ \\
\hline Yes & $33(33.0)$ \\
\hline Post surgical therapy & \\
\hline None & $167(51.4)$ \\
\hline Radiotherapy & $83(25.5)$ \\
\hline Chemotherapy & $24(7.4)$ \\
\hline Chemoradiotherapy & $51(15.7)$ \\
\hline
\end{tabular}

\section{CONCLUSIONS}

Although we acknowledge the limitations of the study design, this retrospective series demonstrated the safety of laparoscopic radical treatment of patients with CC as demonstrated by the low rate of recurrence. 